\title{
POTENSI SOSIAL BUDAYA MASYARAKAT DUSUN CETHO SEBAGAI EMBRIO EKOWISATA RAKYAT DI KABUPATEN KARANGANYAR
}

\author{
Emy Wuryani dan Wahyu Purwiyastuti \\ Program Studi S1 Pendidikan Sejarah \\ FKIP Universitas Kristen Satya Wacana
}

\begin{abstract}
Ecotourism is not the matter of ecology and economics, but also the evaluation and opinions from society. That means it suppose to be managed by them which is starting from the planning, implementation, and benefit of it. The popularity of Cetho village society who live around the Cetho Temple seem are unprofitable by the exotic of that temple. The exotic of the temple indeed has been a big attraction for the domestic and foreign tourists. As a matter of fact that is interesting to be observed. Therefore, the problem is to be observed in this research is what are the potential resources of socio-culture in Cetho village, and how the Government and Tourism Organization Motivator have made the potential resources from this society. The result of this research that 1) Beganjuran Art (the Balinese instrument in procession the Balinese dance in the Hinduism ritual) in Cetho Temple, the story and legend of Cetho Hinduism was the ancestor of Balinese Hinduism People. 2) The ritual of voluntary collective work or mutual aid every Sunday morning is a solidarity among them. 3) Cetho people say, the contribution for them which is done by the Goverment not yet maximal. According to the Tourism Service of Karanganyar Regency, the contribution has been given only for facility and in helping to propagate the potency of society. If the tourism activity will be used of course that very depends to the budget plan from central government, such as through the tourism PNPM programme.
\end{abstract}

Key words: the Cetho hinduism people, the public ecotourism, empowering of the society potency

\section{PENDAHULUAN}

Pariwisata tidak dapat dilepaskan dari kebudayaan suatu masyarakat. Mengingat bahwa penilaian positif atau negatif, setuju atau tidak setuju, baik atau buruk, adalah sesuatu yang sangat diwarnai oleh konteks kebudayaan masyarakat yang berkunjung ke lokasi itu maupun masyarakat yang dikunjungi (J.J. Spillane: 1994). Ekowisata adalah kegiatan wisata yang bertumpu pada usaha pelestarian fungsi sumber daya alam dan budaya sebagai daya tarik yang dapat dijadikan sumber ekonomi berkelanjutan. Oleh karena itu, kegiatan ekowisata harus dikelola berdasarkan prinsip-prinsip pembangunan berkelanjutan (sustainable development) sehingga dapat memberikan manfaat kepada generasi sekarang dan generasi yang akan datang (Oka Yoeti, 2000)

Industri pariwisata dan wisatawan pada saat ini berlomba untuk mencari obyek wisata yang masih asli. Setiap penemuan obyek wisata merupakan suatu "prestasi" tersendiri. Panorama keindahan alam, situs kebudayaan, sikap hidup atau perilaku, dan sebagainya yang belum pernah terjamah oleh wisatawan merupakan sesuatu yang sangat dicari oleh wisatawan. Kategori luar biasa akan diberikan untuk situs-situs kebudayaan yang tidak pernah terjamah sebelumnya. Gengsi dan prestise dianggap akan dimiliki oleh 
seseorang bila ia mampu berwisata ke tempat-tempat di mana belum ada wisatawan yang menaruh perhatian sebelumnya.

Di bidang pariwisata, Kabupaten Karanganyar memiliki banyak sekali aset wisata yang potensial, baik obyek wisata alam, budaya maupun obyek wisata buatan yang sudah berkembang. Untuk mengembangkan Daerah Tujuan Wisata (DTW), pemerintah Kabupaten Karanganyar telah membagi tiga zona atau wilayah pengembangan wisata. Zona A adalah Tawangmangu yang berada persis di kaki Gunung Lawu. Di kawasan wisata Tawangmangu terdapat beberapa obyek wisata untuk rekreasi wisata alam dan wisata agro. Zona B adalah Kecamatan Matesih dan sekitarnya. Di wilayah itu paling cocok dikembangkan wisata ziarah dan sejarah. Sebab terdapat situs purbakala Watu Betek dan situs Watu Kandang dan permandian Sapta Tirta Pablengan. Kemudian Astana Giribangun, Mangadeg, dan Girilayu di Desa Karangbangun, merupakan tempat makam raja-raja keturunan Pura Mangkunegaran, Surakarta. Zona C selain untuk wisata sejarah karena terdapat situs purbakala, zona ini juga untuk agrowisata. Di wilayah ini terdapat obyek wisata: Candi Sukuh dan Candi Cetho, Goa Tlorong dan Gunung Kembar, agrowisata kebun teh dan bunga krisan, taman hutan raya (Tahura) dan taman semar. Untuk menjadikan pariwisata Karanganyar di pentas nasional dan internasional, pemerintah kabupaten melakukan kerjasama dan membuka akses baru dengan berbagai pihak. Kerjasama antara lain dengan beberapa pemerintah daerah seperti Bali, Batam, dan Solo serta dengan pihak swasta seperti beberapa biro perjalanan maupun maskapai penerbangan (Dinas Pariwisata Jawa Tengah, 2006)

Dusun Cetho, desa Gumeng, kecamatan Jenawi, Kabupaten Karanganyar merupakan salah satu Daerah Tujuan Wisata (DTW) di Jawa Tengah yang memiliki pesona candi Cetho dan alam pegunungan yang beriklim sejuk. Komunitas masyarakat dusun Cetho hidupnya masih kental dengan sistem keagamaan Hindu dan memiliki ketahanan sistem keagamaan yang kuat. Masyarakat Hindu di dusun Cetho melangsungkan interaksi secara harmonis, hidup berdampingan dengan pemeluk agama lain seperti Islam dan Kristen.

Dusun Cetho merupakan desa adat yang mayoritas penduduknya memeluk agama Hindu-Jawa. Jumlah pemeluk agama Hindu di desa adat Cetho sebanyak 270 orang, sedangkan jumlah pemeluk agama Islam hanya sekitar 8 orang (Kabupaten Karanganyar dalam Angka, 2006). Mata pencaharian penduduk umumnya bertani. Aktivitas sosial kemasyarakatan di desa adat Cetho berjalan sebagaimana layaknya penduduk desa lain. Pada setiap bulan, khususnya kaum wanita, mempunyai kegiatan rutin pertemuan PKK. Di tingkat RT dan RW juga diselenggarakan pertemuan rutin yang diikuti kaum pria dan Karangtaruna. Pertemuan diselenggarakan setiap Selasa kliwon, Minggu kliwon atau Rabu legi. Akulturasi antara budaya Jawa dan agama Hindu sangat terasa di Cetho. Kondisi yang demikian menarik untuk dilakukan penelitian. Hal ini mengingat cukup banyak potensi desa yang dapat dikembangkan sebagai ekowisata dengan harapan dapat meningkatkan ekonomi masyarakat dan untuk melestarikan budaya dan lingkungannya.

\section{TINJAUAN PUSTAKA}

\section{Ekowisata}

Ekowisata adalah kegiatan wisata yang bertumpu pada usaha pelestarian fungsi sumber daya alam dan budaya sebagai daya tarik yang dapat dijadikan sumber ekonomi berkelanjutan. Oleh karena itu kegiatan ekowisata harus dikelola berdasarkan prinsip-prinsip pembangunan berkelanjutan (sustainable development) sehingga dapat memberikan manfaat, baik kepada generasi sekarang maupun yang akan datang. (Oka Yoeti, 2000) 
Definisi Ekowisata menurut Hector Ceballos-Lascurain (1987) adalah perjalanan ke tempat-tempat alami yang relatif masih belum terganggu atau terkontaminasi (tercemari) dengan tujuan untuk mempelajari, mengagumi dan menikmati pemandangan, tumbuh-tumbuhan dan satwa liar, serta bentuk-bentuk manifestasi budaya masyarakat yang ada, baik dari masa lampau maupun masa kini."

Sedangkan pengertian Ekowisata Berbasis Komunitas (community-based ecotourism) merupakan usaha ekowisata yang dimiliki, dikelola dan diawasi oleh masyarakat setempat. Masyarakat berperan aktif dalam kegiatan pengembangan ekowisata dari mulai perencanaan, implementasi, monitoring dan evaluasi. Hasil kegiatan ekowisata sebanyak mungkin dinikmati oleh masyarakat setempat. Jadi dalam hal ini masyarakat memiliki wewenang yang memadai untuk mengendalikan kegiatan ekowisata(OkaA. Yoeti, 2000).

\section{METODE PENELITIAN}

Metode yang digunakan dalam tulisan ini adalah Sejarah Lisan, Penelusuran Arsip dan Studi Kepustakaan. Cara ini digunakan untuk memperoleh informasi pendahuluan tentang gambaran umum Kabupaten Karanganyar dan secara spesifik mengenai peristiwa sejarah hidup masyarakat dusun Cetho. Perkembangan sosial budaya masyarakat dusun Cetho tentu sangat erat kaitannya dengan keberadaan candi Cetho. Wawancara mendalam, teknik ini digunakan untuk memperoleh data mengenai aktivitas sosial, kultural, religius, dan sebagainya. Dokumentasi, digunakan untuk mendokumentasikan dan merekam segala aktivitas sosial budaya masyarakat dusun Cetho dengan menggunakan alat perekam, kamera digital dan handycam. Observasi langsung dilaksanakan di lingkungan tempat tinggal dan komunitas masyarakat dusun Cetho untuk memperoleh gambaran umum mengenai potensi sosial dan budaya serta segala aktivitas masyarakatnya.

Teknik yang digunakan untuk menganalisa data melalui cara membuat interpretasi sejarah data pada arsip terkait dengan aspek sosial budaya masyarakat. Data hasil wawancara dianalisa secara deskriptif naratif. Sejarah naratif mendeskripsikan masa lampau dengan merekonstruksi "apa yang terjadi" serta diuraikan sebagai narasi (cerita), dengan percatatan lain "kejadian-kejadian" penting diseleksi dan diatur menurut poros waktu sehingga tersusun sebagai sebuah narasi atau cerita (Sartono Kartodirdjo, 1992).

\section{POTENSI SOSIAL BUDAYA MASYARAKAT DUSUN CETHO}

\section{Kerajinan Tangan}

Jumlah pengrajin souvenir atau cinderamata di dusun Cetho masih sedikit sekali. Dari sekitar 436 penduduk laki-laki di dusun Cetho, hanya 3 orang saja yang menjadi pengrajin dan mempunyai keterampilan membuat kerajinan tangan berbahan baku dari kayu. Kayu yang digunakan sebagai bahan baku tersebut oleh masyarakat setempat disebut dengan "kayu bertuah", yaitu jenis-jenis kayu yang secara kodrati mengandung dan mempunyai daya kekuatan atau energi serta daya supranatural yang bukan dari hasil rekayasa manusia.

Kayu bertuah diyakini sebagai perlengkapan (ubo rampe) untuk kehidupan sehari-hari dan diyakini sebagai anugerah dari Tuhan. Kerajinan tangan kayu bertuah bagi pengrajin hanya sebagai pekerjaan sampingan untuk mendapatkan penghasilan tambahan.

Kayu bertuah terdiri dari kayu jenis Liwung, Tawa/Mentawa, Lotrok, Kebak, Prono Kuning dan Kengkeng. Jenis-jenis kayu ini bisa ditemui di dalam hutan-hutan di Gunung Lawu. Manfaat atau tuah dari masing-masing jenis kayu dapat dijelaskan sebagai berikut: 
a. Kayu Liwung: diyakini dapat membawa keluhuran, kewibawaan, dan keselamatan. Bentuk penggunaan dari Kayu Liwung dapat berupa tasbih sebagai sarana meditasi, tongkat, dan gelang.

b. Kayu Tawa/Mentawa: sebagai penawar daya atau kekuatan negatif. Cara penggunaannya ialah kayu direndam dalam air, kemudian berdoa pada Tuhan. Setelah air hasil rendaman kayu ini didoakan, maka air bisa diminum, untuk mandi atau disiram pada halaman rumah, juga dapat melindungi ternak dari pagebluk atau bencana.

c. Kayu Lotrok: bertuah dalam menghilangkan hambatan dan memberi keselamatan. Kayu jenis ini juga dipercaya sangat membantu dalam proses kelahiran bayi. Penggunaanya sama dengan Kayu Tawa/ Mentawa.

d. Kayu Kebak: diyakini oleh masyarakat dapat memperlancar rejeki. Kayu Kebak biasanya dipotong kecil, kemudian bisa disimpan di dompet, meja dagangan, laci/kotak uang.

e. Kayu Kengkeng: mempunyai tuah keselamatan dan ketenangan. Secara khusus kayu ini diyakini dapat menjaga bayi yang baru lahir dengan meletakkan kayu di bawah bantal.

f. Kayu Prono Kuning: untuk pengobatan dari segala penyakit dalam. Cara penggunaannya yaitu kayu direndam atau direbus kemudian diminum setelah air berubah menjadi warna kuning.

Selain kayu-kayu tersebut di atas masih ada jenis kayu lain yang dianggap bertuah yang dapat ditemukan di daerah lain di wilayah Indonesia, misalnya kayu: Setigi, Secang, Nagasari, Dewadaru, Galih Asem, dan Galih Kelor.

Jenis-jenis kayu bertuah tidak dapat ditemui di sembarang tempat. Di dusun Cetho, kayu ini didapatkan di dalam hutan-hutan di lereng gunung Lawu. Untuk menuju lokasi keberadaan kayu, pengrajin biasanya harus berjalan kaki karena medannya terjal dan bebatuan, sehingga tidak dapat dijangkau dengan kendaraan dan tidak sembarang orang dapat mengambilnya. Biasanya pengrajin harus mencari hari baik dahulu sebelum mencari kayu bertuah. Hari baik ini dihitung berdasarkan hari pasaran dalam kepercayaan orang Jawa. Sedangkan keberadaan kayu yang akan diambil tidak pasti, kadang berada di dalam hutan-hutan di kaki gunung Lawu sebelah barat, namun pada hari atau bulan berikutnya jika pengrajin mencari kayu di tempat yang sama maka kayu itu tidak dapat ditemui lagi. Di kemudian hari, kayu yang dicari ditemukan di sisi lain seperti misalnya di lereng gunung Lawu sebelah utara, timur, atau selatan. Inilah yang menjadi salah satu keunikan dari kayu bertuah.

Pengetahuan masyarakat setempat tentang adanya kayu bertuah didapatkan dari para leluhur Dusun Cetho yang mewariskan pengetahuannya kepada anak cucunya sampai sekarang. Ketrampilan pengrajin pada awalnya juga diperoleh secara turun-temurun. Sekitar tahun 1995, kerajinan tangan dari kayu bertuah mulai muncul dan pengembangan dengan bentuk yang lebih bervariasi baru muncul pada sekitar 4-5 tahun yang lalu dan merupakan ide/kreativitas serta ketrampilan dari para pengrajin sendiri. Kayu bertuah oleh pengrajin diolah dalam bentuk tasbih, gelang, kalung, pipa rokok dan tongkat komando (tongkat dengan panjang kurang lebih $80 \mathrm{~cm}$ )

Proses pembuatan cinderamata yang memakan waktu cukup lama dianggap sebagai kendala bagi para pengrajin dalam mengembangkan usaha ini. Di samping itu, keterbatasan peralatan dan bahan baku terkadang juga mengakibatkan proses pengolahan kayu terhambat. Dalam mengolah kayu-kayu yang sudah didapatkan, pengrajin masih menggunakan alat-alat yang sederhana walaupun sudah berbau teknologi seperti alat bor. Biasanya pengrajin dalam mengolah kayu bertuah lebih bersifat perseorangan dan tertutup. Mereka membuatnya di dalam rumah masing-masing, tidak pernah diperlihatkan kepada para wisatawan dan pengunjung obyek wisata Candi Cetho. Belum ada perkumpulan atau organisasi yang mengorganisir para pengrajin untuk mengembangkan model atau bentuk kerajinan tangan di dusun Cetho agar lebih 
bervariasi dan lebih menarik. Bentuk dan kurangnya variasi cinderamata di dusun Cetho ini menyebabkan wisatawan kurang tertarik untuk membelinya.

Menurut salah seorang penduduk asli dusun Cetho yaitu bapak Kasmin (41 tahun), dusun Cetho ini memiliki potensi kerajinan tangan yang sebenarnya dapat dimanfaatkan sebagai hasil karya seni yang dapat dibanggakan. Kerajinan tangan di dusun ini diprakarsai oleh Bapak Winarno (34 tahun). Meski hanya berpendidikan SMP, pak Winarno memiliki daya kreativitas untuk mengembangkan kerajinan tangan di dusun Cetho. Pengetahuan dan keahlian kerajinan yang telah dimiliki oleh pengrajin dusun Cetho berasal dari keterampilan yang telah dimiliki kemudian dilatih secara terus menerus.

\section{Tradisi/Upacara dan Kesenian}

Agama Hindu merupakan agama mayoritas masyarakat dusun Cetho, jumlah pemeluk Hindu sekitar 90 persen dan sisanya, kurang lebih 10 pesen memeluk agama Islam. Agama Hindu merupakan agama turun-temurun dari nenek moyang mereka, sedangkan masyarakat pemeluk agama Islam umumnya adalah warga pendatang. Warga pendatang antara lain berprofesi sebagai guru dan pedagang. Ada juga kaum pria dari dusun Cetho yang memperistri wanita dari luar daerah, yang beragama Islam. Kehadiran unsur agama di suatu daerah, secara tidak langsung menghasilkan budaya, dan budaya tersebut adalah upacara keagamaan dan upacara adat. Upacara keagamaan di dusun Cetho antara lain: a) Hari Raya Nyepi. Sehari sebelum merayakan Nyepi, masyarakat desa Cetho menuju Candi Prambanan untuk bersemedi/ bersembahyang. Apabila ada yang tidak dapat ke Prambanan mereka tetap beribadah di pelataran Candi Cetho untuk bersembahyang. Pada hari raya Nyepi tidak ada aktivitas di desa Cetho selama satu hari penuh. b) Galungan. Upacara galungan bagi umat Hindu dusun Cetho dilaksanakan dua kali dalam satu tahun. Pelaksanaannya di plataran candi sebagai tempat sembahyang seluruh warga. Upacara galungan ini dilaksanakan pada hari Rabu kliwon menurut kalender Hindu dari Bali. c) Upacara Saraswati. Tempat upacara keagamaan ini di Pura Saraswati, Terletak 300 meter dari candi Cetho. Upacara ini dilaksanakan pada hari Sabtu Legi setiap bulan menurut kalender Hindu dari Bali. d) Upacara Adat Mondosiyo. Upacara adat mondosiyo dilaksanakan oleh masyarakat Cetho sebagai rasa syukur kepada Danyang Kyai Grincing Wesi. Mondosiyo merupakan upacara bersih desa yang tujuannya agar masyarakat dan alam di dusun Cetho terbebas dari segala macam musibah. Upacara mondosiyo dilaksanakan setahun sekali pada hari Selasa Kliwon tahun Wuku menurut kalender Hindu bertempat di pelataran candi Cetho. Pada malam harinya diselenggarakan pentas wayang kulit, biayanya dari swadaya masyarakat Cetho. Pelaksanaan upacara mondosiyo diatur dalam tradisi masyarakat Hindu, yaitu apabila sudah dilakukan tujuh kali berturut-turut maka pada pelaksanaan yang kedelapan upacara ini ditiadakan/diliburkan. Oleh karena itu biasanya upacara yang ketujuh merupakan puncak acara mondosiyo yang diselenggarakan lebih besar dibanding ketujuh prosesi Mondosiyo sebelumnya. Untuk acara kondangan setiap kepala keluarga membawa 2 tumpeng, komplit dengan lauk pauk diantaranya bothok dan ayam panggang. Mondosiyo merupakan salah satu bentuk kerukunan antar umat beragama dalam masyarakat dusun Cetho.

Selain di candi Cetho sebagai candi utama, ritual dan upacara juga ada yang dilaksanakan di Puri Saraswati. Setiap hari raya kebesaran agama Hindu (Nyepi, Galungan, Hari Saraswati, dan sebagainya) maka masyarakat dusun Cetho maupun pengunjung dari luar dusun Cetho juga melakukan tradisi dan upacara di puri ini. Mereka bersembahyang dan berdoa dengan menyalakan dupa dan meletakkan bunga mawar di depan patung dewi Saraswati. Dewi Saraswati dalam kepercayaan Hindu merupakan dewi pengetahuan. Setelah upacara dan ritual selesai, kebaya yang biasanya diletakkan di samping sesaji harus diganti dengan dengan kebaya yang baru. Hal ini merupakan lambang pembersihan dan kesucian dewi Saraswati. 
Di plataran Puri Saraswati juga sering dilaksanakan tradisi pagelaran tari yang berkaitan dengan kepercayaan Hindu. Pagelaran tari ini biasanya didatangkan langsung dari Bali. Pemrakarsa pagelaran tari datang dari pejabat-pejabat, seperti misalnya pagelaran tari yang digagas oleh Bupati Gianyar dan Karang Asem. Sebaliknya, masyarakat dusun Cetho sendiri belum pernah berinisiatifmenyelenggarakan pagelaranpagelaran di puri Saraswati.

Di sebelah Puri Saraswati terdapat sebuah sendang kuno yang ditemukan bersamaan dengan candi Cetho. Di sendang ini biasanya pengunjung melakukan tradisi melempar uang koin ke dalam air dan membasuh muka, tangan, maupun kaki mereka dengan air dari sendang. Bagi yang percaya dan yakin, maka tradisi ini merupakan bentuk harapan dan doa agar memperoleh kelancaran dalam mencari jodoh, mendapat rejeki dan kesehatan. Air dari sendang ini juga diyakini memiliki banyak khasiat salah satunya dapat menyembuhkan penyakit. Sebagai upacara penghormatan dan rasa syukur terhadap dewa air, di sendang ini diselenggarakan upacara Dawuan setiap enam bulan sekali pada hari Sabtu Kliwon berupa kondangan. Dawuan diselenggarakan dengan maksud meminta kelancaran mata air.

Dalam kompleks candi Cetho juga terdapat sebuah candi yang letaknya cukup jauh dari candi utama yakni candi Kethek (kethek dalam bahasa Indonesia berarti monyet). Dinamakan candi kethek karena pada saat ditemukannya candi terdapat sebuah patung monyet, namun sekarang patung itu sudah hilang dan tidak diketahui keberadaannya. Candi Kethek memiliki bentuk bangunan yang sama dengan candi Cetho yakni seperti punden berundak dan puncak tertinggi diyakini sebagai lambang kekuasaan. Karena letaknya yang cukup jauh dari candi utama dan sulit dijangkau yakni harus menyeberangi sungai dan melewati jalan setapak dalam perbukitan yang curam dan terjal, sehingga tidak banyak wisatawan atau pengunjung yang mengunjungi candi Kethek. Tidak ada upacara maupun tradisi khusus yang dilaksanakan di Candi Kethek. Namun, pada saat di Candi Cetho yang dianggap sebagai candi utama, Puri Saraswati dan Sendang diselenggarakan upacara maupun tradisi maka beberapa utusan/perwakilan harus ke candi Kethek untuk meletakkan sesaji pada plataran tertinggi. e) Dawuhan. Upacara adat dawuhan dimaksudkan untuk menghormati atau bersyukur kepada Mbah Cikal Bakal yaitu nenek moyang mereka yang dipercaya sebagai pemberi air bagi kehidupan warga dusun Cetho. Biaya penyelenggaraan upacara adat dawuhan berasal dari swadaya masyarakat. Dalam kepercayaannya, masyarakat pantang meminta bantuan dari pemerintah, akan tetapi kalau pemerintah atau ada pihak-pihak lain yang ingin memberikan bantuan mereka tidak menolak. f) Ruwahan. Seperti masyarakat Jawa lainnya, warga masyarakat dusun Cetho juga masih mempertahankan upacara/tradisi ruwahan. Tradisi ini dilaksanakan di pemakaman dusun Cetho dengan didahului acara nyekar atau tabur bunga di makam keluarga masingmasing. Setelah itu tumpeng yang dibawa dimakan bersama-sama dengan seluruh masyarakat dusun Cetho yang hadir di makam. Upacara ruwahan dilaksanakan pada tanggal 15 Ruwah. g) Suranan (1 Suro). Upacara untuk menyambut tahun baru Jawa. Masyarakat dusun Cetho berkumpul di rumah tokoh/kepala dusun semalaman untuk tirakatan. h) Wetonan. Wetonan adalah upacara untuk mengenang hari lahir (weton) dan rasa bersyukur kepada Tuhan karena masih diberi keselamatan. Pelaksanaannya setiap bulan sesuai hari lahirnya masing-masing.

\section{Kesenian}

Beberapa kesenian yang ada di dusun Cetho adalah: a) Karawitan. Kesenian ini pada awalnya cukup berkembang, karena tersedianya peralatan dan adanya pelatih dari Solo dan Bali yang dengan suka rela melatih kerawitan bagi penduduk dusun Cetho. Pelatih sekaligus pemain yang berperan sebagai pengendang (pemegang alat kendang). Namun karena kurang peminat, kelompok karawitan ini pada akhirnya bubar. b) Campursari. Setelah karawitan bubar, masyarakat Cetho kehilangan aktivitas dalam 
berkesenian. Untuk mengganti kesenian karawitan warga membentuk grup campursari. Grup campursari Cetho sempat berjaya pada masanya. Mereka melayani tanggapan antar desa sampai tingkat kecamatan. Campursari juga mengalami kemunduran seiring berkurangnya anggota yang keluar, sedangkan penggantinya belum memadai dan kurangnya regenerasi yang menyebabkan bubarnya grup ini. c) Beganjur. Beganjuran ialah peralatan musik yang dimainkan sebagai latar dalam mengiringi upacara-upacara adat dan agama. Instrumen musik dalam Beganjuran antara lain kendhang, kenong, dan kepyak. Alat musik ini merupakan sumbangan dari bupati Bali dan juga patung dewi Saraswati. Bupati Bali juga mengirimkan tim pelatih untuk membantu masyarakat Cetho. Grup beganjurnya dinamakan "Ganjuran Saraswati Candi Cetho". Sebenarnya Beganjuran ini berasal dari Bali yang dilaksanakan di dusun Cetho untuk pelaksanaan upacara agama dan adat. Untuk melestarikan kesenian ini setiap seminggu sekali dilakukan latihan terutama bagi kaum muda untuk regenerasi agar beganjuran tidak mengalami pergeseran di tengah berkembangnya globalisasi.

\section{Cerita/Legenda}

Agama Hindu di Cetho ini dipercaya masyarakat sebagai leluhur/sesepuh dari Hindu yang berada di Pulau Bali. Agama Hindu ini disebarkan ke Bali karena kerajaan Hindu di Jawa mengalami keruntuhan. Keberadaan Candi Cetho dianggap sebagai tempat suci yang merupakan warisan dari kerajaan Majapahit. Ketika itu Brawijaya V diperlakukan tidak adil oleh anaknya sendiri yaitu Raden Patah. Namun, Brawijaya mau mengalah demi anaknya sehingga Raden Patah dapat menduduki jabatan sebagai Patih, tetapi setelah 500 tahun masyarakat harus kembali ke agama Hindu lagi. Puri Saraswati juga menjadi bagian dari candi Cetho. Puri ini merupakan hasil dari kerjasama antara Bupati Gianyar dan Bupati Karanganyar. Saraswati itu sendiri melambangkan turunnya pengetahuan suci. Susunan batu yang berbentuk kura-kura dalam candi ini melambangkan sumber penyelamat bumi, sebab "bumi niku mambang".

Dalam kaitannya dengan keberadaan Candi Cetho, masyarakat dusun meyakini beberapa hal berikut ini: 1) Candi Cetho merupakan peninggalan Brawijaya yang terakhir. 2) Brawijaya sebagai penguasa gunung Lawu sehingga oleh masyarakat sering menyebutnya "eyang gunung Lawu”. 3) Keberadaan Candi Cetho sebagai pengayom masyarakat Dusun Cetho. 4) Pelataran pertama pada candi Cetho diyakini sebagai rumah Eyang Krincing Wesi yang merupakan dan yang dan sesepuh dusun Cetho. Jika ada seorang warga yang permintaannya terkabulkan atau mempunyai nadar maka ia akan mengadakan syukuran di pelataran pertama dengan menyembelih kambing.

\section{Pekerjaan dan Teknologi}

Jenis pekerjaan masyarakat dusun Cetho meliputi:

\section{Bertani}

Bertani merupakan pekerjaan utama dari masyarakat dusun Cetho. Setiap keluarga mempunyai hak kepemilikan lahan, maka tidak heran bahwa mayoritas penghasilan warga berasal dari hasil pertanian. Dalam mengerjakan lahan pertanian mereka masih menggunakan peralatan sederhana seperti cangkul, sabit, alat penyemprot hama, plastik (untuk pembibitan dan perlindungan tanaman), dan sebagainya. Penggunaan cangkul sampai saat ini masih dipertahankan karena alasan keadaan alam atau geografis lahan pertanian berupa lereng, sehingga pengoperasian alat pertanian modern seperti traktor akan lebih sulit dibanding alat-alat pertanian yang konvensional. Mereka sangat terbuka dengan perkembangan teknologi pertanian, namun karena alasan biaya yang lebih murah lebih memilih alat pertanian yang sederhana dengan biaya yang masih dapat terjangkau. Termasuk dalam pemilihan pupuk bagi tanaman, mayoritas petani di 
dusun Cetho masih memanfaatkan pupuk kompos dari kotoran hewan ternaknya. Pupuk kompos ini bagi petani juga dirasa lebih bagus daripada pupuk kimia yang dapat merusak tanah.

\section{Guru}

Guru yang bertugas di sekolah dusun Cetho umumnya berasal dari luar daerah. Hanya dua orang saja penduduk asli dusun Cetho yang berprofesi sebagai guru. Dusun Cetho memiliki satu Taman KanakKanak dan satu Sekolah Dasar. Pendidikan SMP diselenggarakan pada tingkat Kecamatan. Keberadaan TK di dusun Cetho juga belum lama hal ini terkait dengan program pemerintah yaitu dibangun atas bantuan dana PNPM (Program Nasional Pemberdayaan Masyarakat). Selain Guru juga terdapat pegawai negeri dari Dinas Purbakala yang sudah menetap di desa tersebut.

\section{Pa Mangku}

Pa Mangku berperan sebagai tokoh agama hindu di daerah tersebut. Pa Mangku mempunyai tugas yang berbeda yaitu: Pa Mangku Saraswati (bertugas memimpin doa dan sembahyang di Puri Saraswati); Pa Mangku Gede (bertugas sebagai pemimpin upacara ritual/adat/sembayang di candi), dan Pa Mangku Wasi (bertugas sebagai pemimpin upacara kematian). d) Pekerjaan lain warga dusun cetho adalah sebagai Pegawai Negeri Sipil (PNS), pedagang, dan sebagian sebagai pengusaha pemondokan (homestay), buruh pabrik, pegawai honorer di objek wisata candi Cetho serta pengrajin. Sementara orang-orang yang dianggap memiliki pengetahuan dan kemampuan lebih dalam hal spiritual bertugas sebagai pemuka agama dan pemimpin ritual atau upacara. Selain pekerjaan umum tersebut masyarakat dusun Cetho juga terdapat pekerjaan khusus yaitu sebagai pemangku adat, yang dalam bahasa lokal disebut wasi

\section{Arsitektur}

Rumah warga dusun Cetho mayoritas berbentuk serotong/kampung dan sedikit sekali yang berbentuk limasan. Bentuk rumah ini telah mengalami perubahan, dahulu rumah-rumah masih berbentuk seperti joglo dengan tiang-tiang penyangga yang tinggi dan terbuat dari kayu, namun sekarang bervariasi sesuai perkembangan jaman dan teknologi. Sampai tahun 1980'an pembuatan rumah masih berbahan dasar kayu dan atap dari alang-alang yang diambil dari hutan. Namun karena bahan tersebut mudah terbakar, mudah rapuh, dan tidak cukup kuat bertahan dari air hujan seiring dengan perkembangan teknologi masyarakat mulai membangun rumahnya dengan bahan batu bata, semen dan beratap genting atau seng. Atap dari seng dimaksudkan untuk menahan panas di dalam rumah karena udara di pegunungan yang sangat dingin. Bentuk rumah di dusun Cetho secara umum ialah berbentuk rumah limas dan sebagian juga berbentuk serotong/kampung yang atapnya terbuat dari seng yang berbeda dari daerah perkotaan. Hal ini dikarenakan oleh faktor alam yang suhunya sangat dingin dan tiupan angin yang besar. Atap seng memiliki kelebihan yaitu seng lebih tahan lama menyimpan suhu panas yang kemudian membuat orang yang di dalamnya merasa lebih hangat, lebih tahan terhadap tiupan angin yang kencang dibandingkan atap dari genteng biasa yang jika tertiup angin kencang akan mengakibatkan genteng berantakan. Fungsi rumah bagi warga dusun Cetho secara umum ialah sebagai tempat tinggal, dan dari jarak rumah sekitar 5 meter, warga membangun tempat hewan piaraan, dan kurang dari 3 meter dijadikan lahan pertanian sayur. Selain sebagai tempat tinggal, rumah sekaligus berfungsi sebagai tempat upacara/pertemuan adat. Jika ada pertemuan warga, warga juga diijinkan menggunakan rumah Kepala Dusun sebagai tempat berkumpulnya warga dusun. 


\section{Agama dan Kepercayaan}

Sembilan puluh persen (431 orang) warga Cetho beragama Hindu, dan yang sepuluh persen (5 orang) beragama Islam. Masyarakat dusun Cetho berjumlah $140 \mathrm{KK}$ yang terdiri dari 436 jiwa. Jumlah laki-laki 211 jiwa dan jumlah perempuan 225 jiwa. Mengenai sejarah agama Hindu di dusun Cetho ternyata tidak banyak diketahui oleh masyarakat, hanya beberapa orang tua (sesepuh) dan pemuka/pemangku agama Hindu di dusun Cetho yang mengetahui secara tepat asal mulanya.

Sikap warga yang berbeda agama sangat kooperatif. Pemeluk agama minoritas ikut memegang teguh adat dan tradisi dalam agama Hindu. Tidak pernah terjadi konflik atau perselisihan yang disebabkan oleh perbedaan agama, masyarakat mengutamakan kebersamaan dan kegotongroyongan dalam mengerjakan sesuatu. Saat umat Hindu sedang merayakan hari raya maka umat lain menghormati dan tidak menganggu, begitupun sebaliknya. Bahkan ketika dalam pelaksanaan upacara dan ritual Hindu, pemeluk agama lain berusaha ikut membantu dalam persiapan dan pelaksanaannya.

Di antara warga yang berbeda agama tersebut terdapat toleransi dan sikap saling menghargai antar agama. Mereka berpendapat "agamamu adalah agamamu dan agamaku adalah agamaku”. Dengan pandangan yang cukup kuat inilah maka semua konflik antar umat beragama dapat terhindarkan. Sebagai contoh ketika upacara keagamaan upacara Galungan, Modosionan, Saraswati, dan Nyepi, masyarakat baik yang beragama Hindu maupun Islam secara bersamaan mengikuti prosesi upacara. Yang membedakan di antara mereka ialah cara berdoa yang berdasarkan agama masing-masing. Bentuk toleransi lainnya adalah ketika pemeluk agama Hindu melakukan amati geni, amati karya, dan amati lalungan pada hari raya Nyepi, pemeluk agama Islam pun menghormati hari besar itu dengan cara tidak melakukan hal yang dapat merusak konsentrasi pemeluk agama Hindu yang sedang melakukan ritual keagamaannya.

\section{Sistem Pendidikan}

Sebagian besar warga dusun Cetho mengikuti pendidikan formal sampai Sekolah Dasar. Sedangkan pendidikan informal yang diikuti lebih bersifat umum. Pendidikan non formal ini lebih berkaitan dengan agama, kesenian, dan pembuatan makanan dengan jangka waktu pendidikannya tidak menentu. Pendidikan itu diperoleh dari berbagai sumber, misalnya yang sudah berjalan di dusun Cetho ialah pengajaran ketrampilan menjahit dan cara membuat kue oleh kepala dusun, pendidikan tari dan ketrampilan bagi penabuh dari Bali, serta latihan kesenian karawitan dan campursari oleh warga dusun yang berhenti karena masalah biaya. Sebagian besar warga dusun Cetho mengikuti pendidikan non formal yang diadakan oleh pemerintah. Pendidikan non formal ini berkaitan dengan keterampilan dalam bertani.

\section{Pakaian}

Kaum wanita di dusun Cetho sehari-hari mengenakan bawahan rok dan atasan kaos atau kemeja yang sudah lama dipakai. Namun jika sedang berkebun dan mencari rumput atau kayu, mereka biasanya mengenakan celana panjang berbahan kain tipis dan baju/kaos lengan panjang. Beberapa wanita yang sudah tua atau nenek-nenek masih berpakaian tradisional, bawahan jarik dan atasan model kebaya konvensional. Sedangkan kaum pria sudah berpakaian seperti orang-orang kebanyakan di dusun lain, memakai celana panjang, atasan kaos/ kemeja. Pemuda-pemudi banyak yang memakai jaket karena udara yang dingin.

Saat hari-hari khusus seperti hari kebesaran umat Hindu ataupun akan melaksanakan upacara/ ritual/tradisi tertentu maka ada pakaian khusus pula. Kaum wanita mengenakan atasan kebaya dan bawahan jarik. Sedangkan kaum pria mengenakan bawahan jarik yang dibentuk sarung dan lebih longgar. Atribut khusus berupa sabuk dan ikat kepala yang disebut antheng dan $u d h e n g$. 


\section{Kegiatan Waktu Luang}

Jenis kegiatan yang dilakukan warga dusun Cetho dalam memanfaatkan waktu luang dengan berkumpul bersama keluarga di rumah serta bercengkrama dengan tetangga sekitar. Tujuan warga melakukan aktivitas itu ialah untuk menjalin hubungan yang harmonis dalam keluarga di sela-sela kesibukan dan mereka sangat mengutamakan kebersamaan. Kegiatan lainnya, perkumpulan dan pertemuan RT yang diadakan setiap malam Jumat Kliwon dan perkumpulan pemuda setiap satu bulan sekali. Diadakan pula kerja bakti rutin setiap hari minggu pagi.

Ada pula warga yang belajar dan ikut membuat cindera mata di rumah Bapak Winarno. Tujuan masyarakat dusun Cetho melakukan kegiatan ini untuk mengisi waktu luang dan untuk memenuhi kebutuhan hidup, walaupun hanya bersifat pekerjaan sampingan. Mereka melakukan aktivitas ini setelah menyelesaikan pekerjaan bertani di ladang, kira-kira jam 14.00.

Kegiatan lain untuk mengisi waktu luang, pada setiap hari minggu mengadakan kerja bakti yang diikuti oleh kaum pria dan wanita. Mulai jam 06.00 kaum wanita berkumpul dan membersihkan rumput atau sampah di sekitar jalan di perkampungan. Pukul 08.00, giliran para pria yang bekerja bakti membakar sampah-sampah tersebut dan melakukan hal-hal yang lebih berat seperti meratakan jalan-jalan perkampungan dengan menggunakan peralatan cangkul, urusan air bersih dan juga irigasi ladang, dan lain sebagainya.

\section{PEMBERDAYAAN POTENSI SOSIAL BUDAYA MASYARAKAT}

\section{Pemberdayaan menurut pendapat masyarakat dusun Cetho}

Menurut pendapat masyarakat dusun Cetho, pemberdayaan masyarakat yang dilakukan pemerintah selama ini dianggap kurang maksimal, sehingga belum ada perkembangan yang signifikan. Masyarakat menyatakan bahwa potensi wisata yang dimiliki Desa Gumeng Kecamatan Jenawi cukup banyak, dan semua potensi itu layak dijual sebagai aset wisata. Contohnya Air Terjun Sependok, air terjun Seringin, dan goa Siloumeng yang letaknya di dekat kedua air terjun tersebut. Patut disayangkan, bahwa pengelolaan objek wisata tersebut belum dilakukan secara maksimal sehingga belum dinikmati oleh wisatawan. Alasannya antara lain fasilitas jalan menuju objek wisata di desa Gumeng belum baik. Pemerintah Desa bekerjasama dengan Dinas Purbakala pernah mengajukan proposal kepada pemerintah supaya disediakan dana untuk pembuatan jalan menuju air terjun sependok, air terjun Seringin dan Goa Seloumeng. Masyarakat kecewa karena sampai sekarang usulan mereka belum direalisasi oleh pemerintah.

Masyarakat mengharapkan diselenggarakannya penyuluhan atau pembinaan sadarwisata bagi masyarakat setempat karena pengetahuan mereka tentang pariwisata sangat minim. Dinas Pariwisata pernah mengadakan pelatihan Sadar Wisata untuk semua warga dusun Cetho. Pelatihan bertujuan untuk memberikan pemahaman tentang pentingnya menjaga, melindungi, serta merawat benda peninggalan budaya. Selain itu, pernah juga diselenggarakan pelatihan Pemandu Lokal, hanya saja waktu pelaksanaannya cukup singkat dan tidak dilakukan secara rutin.

Banyak pemuda di dusun Cetho yang tertarik belajar musik gamelan dan untuk merespons keinginan warga tersebut, beberapa tokoh masyarakat berinisiatifmengundang pelatih gamelan dari Bali. Masyarakat berlatih gamelan sesuai dengan waktu luang yang mereka miliki, dan disesuaikan dengan jadwal kedatangan pelatih dari Bali. Latihan diselenggarakan secara gratis karena hasil kesenian tersebut biasanya hanya ditampilkan pada saat upacara keagamaan. Dalam usaha melestarikan kesenian di dusun Cetho keterlibatan pemerintah dalam hal ini dinas pariwisata sudah dapat dirasakan oleh masyarakat. Namun, karena seringnya pergantian kepala dinas dan kebijakan yang tidak sesuai dengan kondisi masyarakat, maka tujuan-tujuan 
dari usaha pelestarian dan pengembangan kesenian ini dianggap belum maksimal. Masyarakat sangat mengharapkan peran pemerintah secara lebih intensif dalam membantu melestarikan salah satu budaya yang dimiliki oleh Indonesia, yaitu kesenian Beganjuran yang juga berkembang di dusun Cetho. Peran pemerintah yang ditunggu oleh masyarakat adalah mempublikasikan beganjuran sebagai pelengkap potensi budaya masyarakat Cetho.

Terkait dengan masalah kemampuan administrasi maupun manajerial Sumber Daya Manusia(SDM) yang dimiliki masyarakat Cetho, SDM yang ada di dusun Cetho merasa belum mampu mengembangkan kawasan Cetho karena mereka menghadapi kendala keterbatasan waktu. Masing-masing warga memiliki pekerjaan utama, sebagai petani atau pegawai kantoran, sehingga untuk mengikuti kegiatan pemberdayaan pariwisata belum bisa maksimal. Di samping itu kesadaran masyarakat mengenai pentingnya kegiatan pariwisata di dusun mereka masih kurang. Kebutuhan ekonomi lebih mudah dicukupi melalui pekerjaan di ladang atau di kantor pemerintah/swasta daripada mengandalkan pendapatan yang belum jelas dari sektor pariwisata.

\section{Pemberdayaan dalam pandangan Pemerintah dan Pelaku Pariwisata}

Pemerintah Kabupaten Karanganyar melalui Dinas Pariwisata Kabupaten Karanganyar menyatakan sudah melakukan publikasi tentang keberadaan candi Cetho. Kawasan candi Cetho secara riil merupakan aset beberapa pihak, diantaranya pemerintah provinsi Jawa Tengah, Dinas Purbakala dan Dinas Pariwisata, sehingga dalam hal promosi, semuanya sudah dilaksanakan oleh masing-masing Dinas terkait.

Tahun 2004 pemerintah membangun fasilitas sub terminal wisata di Karangpandan yang dapat diakses menuju candi Cetho. Terminal wisata ini merupakan aset Disperindakop (Dinas Perindustrian, Perdagangan dan Koperasi) Karanganyar. yang berfungsi sebagai tempat parkir wisatawan yang akan memasuki kawasan wisata sekitar kecamatan Jenawi. Awalnya, terminal itu diharapkan menjadi transit bus-bus besar dari luar kota. Dari terminal wisata ke objek yang dituju wisatawan menggunakan bus-bus kecil (minibus). Khusus tujuan candi Cetho, minibus tersebut direncanakan hanya sampai di pintu gerbang menuju dusun Cetho, karena di tempat tersebut kawasannya tidak menanjak dan diperkirakan memadai sebagai lahan parkir. Rencananya, dari parkiran minibus ke atas menuju candi cetho, pemerintah menyediakan kuda sebagai alat transportasi. Ide tersebut dianggap sangat menarik karena mobilitas wisatawan diatur secara bervariasi. Sayang sekali, rencana tersebut sampai dengan saat ini masih berupa wacana. Seandainya suatu saat rencana program transportasi berkuda ini dilaksanakan, tentu akan berdampak positif bagi warga, salah satunya adalah untuk membuka peluang pekerjaan baru sebagai penyedia jasa transportasi kuda.

Kerjasama yang terjalin antara masyarakat Hindu Cetho dengan Hindu Bali tidak hanya dalam bidang kesenian, namun juga dalam kegiatan sosial lainnya. Pemerintah Desa Gumeng pernah mendapat bantuan dua buah Laptop dari komunitas Hindu Bali. Pada saat itu dua orang pemuda Desa diberdayakan untuk mengikuti latihan mengoperasikan komputer jinjing tersebut. Bantuan lain yang diberikan pemerintah Daerah Gianyar kepada Kabupaten Karanganyar adalah berupa dana yang digunakan untuk membangun Puri Saraswati.

Pelaku pariwisata menyarankan, untuk merealisasikan rencana pembuatan desa wisata di kawasan Cetho supaya bekerja sama dengan pemerintah provinsi Jawa Tengah, karena APBD Kabupaten Karanganyar barangkali tidak akan mampu menopang kebutuhan desa wisata. Oleh karena itu pemerintah, akademisi, masyarakat maupun instansi terkait harus memanfaatkan program PNPM Mandiri Pariwisata. Pengembangan desa wisata memerlukan kajian yang lebih kompleks dari pada hanya melakukan penyuluhan sadar wisata pada warga sekitar. Harus ada pendampingan pada masyarakat, mengadakan agenda wisata yang layak jual, promosi wisata, sampai dengan mengorganisasikan wisatawan-wisatawan yang berkunjung 
ke desa wisata tersebut. Sehingga, masyarakat desa merasakan manfaat dari program desa wisata tersebut. Untuk menuju kepada proses tersebut tidak lah mudah, dan membutuhkan biaya yang tidak sedikit. Menurut responden, biasanya kalau sampai pada masalah biaya, para penggerak pariwisata akan menemukan kendala utama yang terkadang sulit dipecahkan.

\section{PENUTUP}

Potensi sosial budaya masyarakat dusun Cetho, desa Gumeng, Kecamatan Jenawi, Kabupaten Karanganyar berupa: kerajinan tangan aneka kayu bertuah, tradisi/upacara dan kesenian, cerita/legenda dusun Cetho, pekerjaan dan teknologi, arsitektur, dsb. yang berkembang dan mampu bertahan menghadapi arus kemajuan teknologi dan informasi. Kemampuan berkembang dan bertahan menghadapi kemajuan jaman tersebut di samping didorong oleh faktor semangat kebersamaan dan kegotongroyongan juga karena adanya toleransi diantara sesama warga serta peran pemangku adat yang masih kuat. Di sisi lain dalam upaya mengembangkan masyarakat dusun Cetho, peran serta dan cara-cara yang dilakukan Pemerintah dan Lembaga penggerak pariwisata dalam memberdayakan masyarakat setempat sudah cukup banyak namun belum maksimal. Kendalanya adalah belum adanya sinergisme antara pemerintah, penggerak pariwisata, dan masyarakat dusun Cetho dalam menyatukan persepsi pengembangan dusun Cetho sebagai ekowisata rakyat.

\section{DAFTAR PUSTAKA}

Dinas Pariwisata Jawa Tengah. 2006. Aksesibilitas dan Potensi Pariwisata Jawa Tengah. 2005. Semarang: Diparta Provinsi Jawa Tengah.

Kabupaten Karanganyar dalam Angka. 2006

Oka A. Yoeti. 2000. Ekowisata, Pariwisata Berwawasan Lingkungan Hidup. Jakarta: Penerbit P.T. Pertja.

Sartono Kartodirdjo. 1992. Pendekatan Ilmu Sosial Dalam Metodologi Sejarah. Jakarta: Penerbit Gramedia Pustaka Utama.

Spillane, James. 1994. Pariwisata Indonesia, Siasat Ekonomi dan Rekayasa Kebudayaan, Yogyakarta: Kanisius. 